\title{
Erratum to: Association Between DARPP-32 Gene Polymorphism and Personality Traits in Healthy Chinese-Han Subjects
}

Jingying Li • Huan Ma • Hongxu Zhou • Yinglin Huang • Lijuan Wu • Jun Li • Gang Zhu

Published online: 28 June 2013

(C) Springer Science+Business Media New York 2013

Erratum to: J Mol Neurosci (2011) 44:48-52

DOI 10.1007/s12031-011-9505-7

The original version of this article ${ }^{1}$ unfortunately contained several mistakes in the section of "Polymorphism Genotyping". The original order of restriction enzymes (Avall, BccI, and HphI) should be changed to "HphI, AvaП, and Bccl". The primers of rs 879606 should be "(sense: 5'CATACAGGGA CTTGAGCCA3'; antisense: 5'GCATTCAGAAGCAGGG TT3')". The manufacturer of Techne DNA Thermal Cycler should be "(Biometra, Göttingen, Germany)". PCR product of rs879606 should be $524 \mathrm{bp}$, but not $522 \mathrm{bp}$.

The authors apologize to readers for mistakes.

\section{References:}

1. Li J, Ma H, Zhou H, Huang Y, Wu L, Li J, Zhu G (2011) Association Between DARPP-32 Gene Polymorphism and Personality Traits in Healthy Chinese-Han Subjects. J Mol Neurosci 44:48-52

The online version of the original article can be found at http://dx.doi.org/ 10.1007/s12031-011-9505-7.

$\mathrm{J} . \mathrm{Li} \cdot \mathrm{H} . \mathrm{Ma} \cdot \mathrm{H}$. Zhou $\cdot$ Y. Huang $\cdot$ L. Wu $\cdot$ J. Li $\cdot$ G. Zhu $(\bowtie)$

Department of Psychiatry, The First Affiliated Hospital of China

Medical University, Shenyang 110001, China

e-mail: gzhu@mail.cmu.edu.cn 